\title{
Evaluation of Urban Wetland Ecosystem Service Value in Zhuzhou City
}

\author{
Wen Zhan*, Huifeng Cheng**† and Shouyun Shen* \\ *Central South University of Forestry and Technology, Changsha 410004, China \\ **Changsha Environmental Protection College, Changsha 410018, China \\ †Corresponding author: Huifeng Cheng; chenghuifeng_cepc@163.com
}

Nat. Env. \& Poll. Tech. Website: www.neptjournal.com

Received: 15-07-2019

Accepted: 06-10-2019

Key Words:

Zhuzhou city;

Urban wetland;

Double counting;

Ecosystem service value

\begin{abstract}
Zhuzhou is an important part of the Changsha-Zhuzhou-Xiangtan city group in southern China. To grasp the economic benefits of urban wetland resources value in Zhuzhou City, strengthen wetland conservation and utilization, and ensure the sustainable development of cities, this paper takes Zhuzhou 2016 wetland remote sensing image interpretation map and multi-source data as the foundation, and build urban wetland ecosystem service evaluation system. Through deduplicate double counting, this paper evaluates the value of urban wetland ecosystem service in Zhuzhou City employing shadow project method, replacement cost method, travel cost method, conditional value method and other economic value evaluation methods. The results indicate: (a) The total value of urban wetland ecosystem services is $\$ 1,527,908,900$ in 2016 . (b) The ultimate value of urban wetland services ranked as follows: water storage regulation value $(\$ 539,566,265)$, climate regulation value $(\$ 424,930,361)$, tourism recreation value $(\$ 174,543,328)$, water supply value $(\$ 133,183,901)$, biological product value $(\$ 121,987,952)$, atmospheric composition regulation value $(\$ 92,111,687)$, soil erosion prevention value $(\$ 15,799,608)$, water purification value $(\$ 14,598,298)$, and aesthetic heritage value $(\$ 10,075,346)$; (c) The value of different types of wetlands ranked as follows: paddy fields $(\$ 526,111,672)$, riverine wetland $(\$ 526,111,672)$, ponds $(\$ 329,628,343)$, reservoirs $(\$ 149,275,241)$, wastewater treatment plant (\$207,831/a); (d) The value per unit area of different types of wetlands ranked as follows: reservoirs $(\$ 240,919 / \mathrm{ha})$, riverine wetland $(\$ 236,627 / \mathrm{ha})$, pond $(\$ 145,693 / \mathrm{ha})$, paddy fields $(\$ 26,551 / \mathrm{ha})$ and wastewater treatment plant $(\$ 17,003 / \mathrm{ha})$. The evaluation results reveal the great contribution of urban wetland system service to the Zhuzhou city with numbers, that not only provides data basis for wetland conservation and management but also provides a reference for the refined evaluation of urban wetland ecosystem service value.
\end{abstract}

\section{INTRODUCTION}

Wetland ecosystem services refer to the direct or indirect contribution of wetland ecosystems to human well-being and benefits (USEPA 2009, TEEB 2010). The study of wetland ecosystem services began in the middle and late 20th century. With the emergence of global environmental issues, this work has gradually become one of the hot topics of concern in ecology and economics. Numerous international organizations, experts and scholars have carried out a lot of research on wetland ecosystem services in terms of concept definition (Costanza et al. 1997, MA 2005, Wallace 2007, Boyd \& Banzhaf 2007, Fisher \& Kerry 2008, Fisher et al. 2008, Fisher et al. 2009), classification method (Daily 1997, De Groot et al. 2002, Woodward \& Wui 2001, Brander et al. 2006, De et al. 2006), evaluation method (Costanza 2008, Adamus et al. 1987, Odum \& Nilsson 1996, Turner et al. 2010, Hawkins 2003), and value evaluation (Hoekstra \& Hung 2002, Nelson et al. 2009, Musamba et al. 2012, Jiang et al. 2015, De et al. 2012, Sun et al. 2018, Zhao \& He 2018).
Through many cases, it has fully revealed the multi-faceted ecosystem service functions and values provided by wetlands for human society. Among these wetland case types, natural wetlands outside the urban area are the main targets of ecosystem service value assessment research, while research on urban wetlands is relatively rare.

Wetlands are the birthplace of human "civilization" and are closely related to the beginning and decline of the city. On the one hand, wetlands provide many natural resources and material basis for the urban production and life, which provide a strong guarantee for the urban ecological balance and social development, while on the other hand, under the background of intensified global urbanization, human activities have caused serious disturbance and damage to wetlands, especially the shrinking area and increasing degree of fragmentation of wetlands within the urban area, and their ecosystem services are also affected in many aspects. The evaluation of urban wetland ecosystem service value is a process of quantitative evaluation of multiple service values 
of various types of wetlands within the city, which provides scientific data support for comprehensive protection and utilization of wetlands and sustainable development of the city (De et al. 2006).

At present, the economic value evaluation method is the most widely used one in many wetland ecosystem service evaluation methods. It is a quantitative assessment of the monetization of wetland ecosystem services. It not only reflects the impact of human activities on the structure and function of wetland ecosystem (Costanza et al. 2014), but also provides a basis for ecological compensation decision-making (Farley et al. 2010), and improves people's understanding of the importance of wetland ecosystem services (Braat et al. 2012).

Zhuzhou is an old industrial base in southern China. Its natural conditions are superior and its wetland resources are abundant. The Xiangjiang River flows through the city from south to north, dividing the urban area into two sides. In the past, the characteristics of traditional industries dominated by heavy chemical industry have caused huge consumption of natural resources in Zhuzhou City, which has caused a great impact on urban wetlands, serious water pollution, and the shrinking of wetland area and quantity. In the 21st century, Zhuzhou has become an important part of Changsha-Zhuzhou-Tan urban agglomeration, which is a demonstration area of "two-oriented society construction". Its urbanization process is intensifying and the urban area is expanding. Therefore, coordinating urban sustainable development and wetland conservation and utilization has become the focus of government and society. It is urgent to scientifically evaluate the value of wetland ecosystem services in Zhuzhou City, and provide a reference for management decision-makers. Based on the socio-economic environment of Zhuzhou City and the ecological characteristics of wetlands, this paper evaluates the value of urban wetland ecosystem services by various suitable economic value evaluation methods and reveals the wetland ecosystem services to provide urban survival and development with intuitive economic figures.

\section{MATERIALS AND METHODS}

\section{Research Area Overview}

Zhuzhou located in the east of Hunan province in China, in the west of Luoxiao Mountain Range, Nanling Mountains Range to the tilting area of Jianghan Plain, and the downstream of the Xiangjiang River water system, between the northern latitude $26^{\circ} 03^{\prime} 05^{\prime}$ " $28^{\circ} 01^{\prime} 07^{\prime}$ ", east longitude $112^{\circ} 57^{\prime} 30^{\prime \prime} \sim 114^{\circ} 07^{\prime} 15^{\prime \prime}$ (Fig. 1). Zhuzhou is a subtropical monsoon humid climate, four seasons, adequate rainfall, and rich in wetland resources. As of 2016, the total area of Zhuzhou (including city and counties) is about 11247.55 $\mathrm{km}^{2}$, of which the urban area is located in the northwest of Zhuzhou with an area of $853.4 \mathrm{k} \mathrm{km}^{2}$ and a permanent resident population of about 4,016,300. This paper takes 2016 urban area (Zhuzhou City) as the specific research area, covering urban planning area and built-up area.

\section{Classification of Urban Wetland in Zhuzhou City}

The concept of urban wetlands does not currently have a scientific definition in a strict sense. The academic community

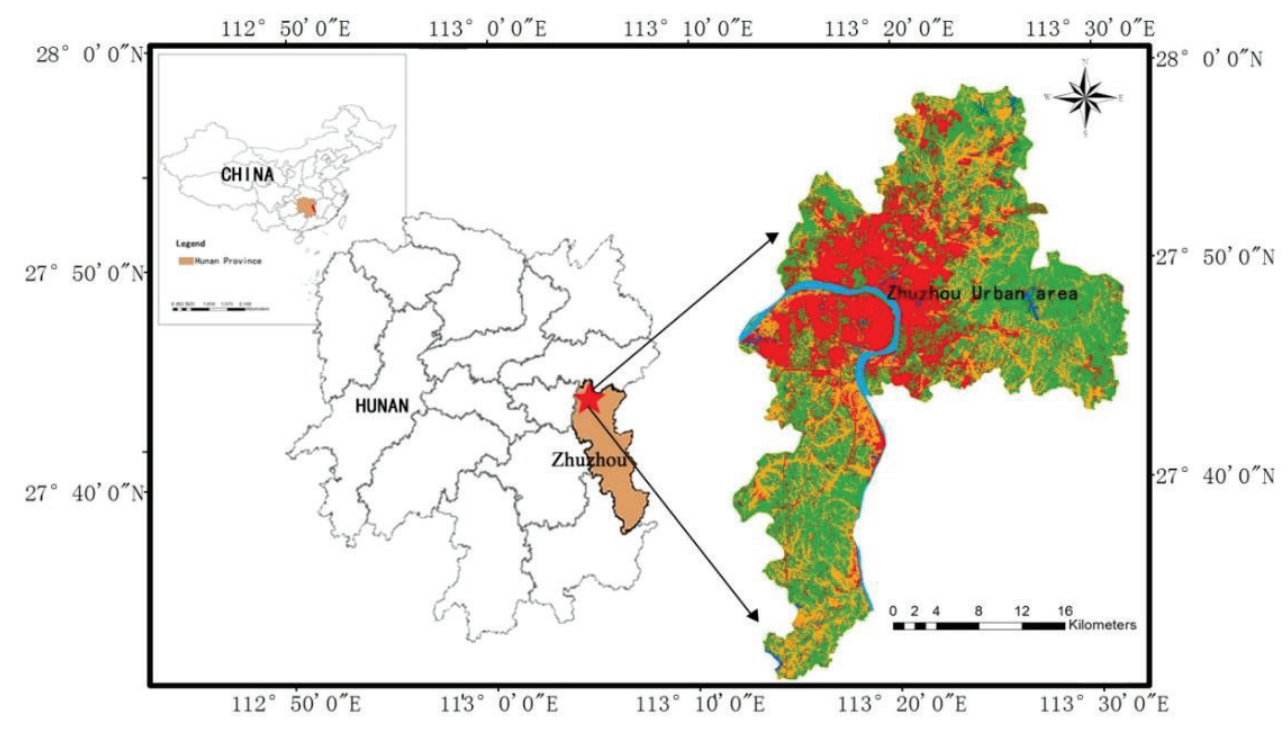

Fig. 1: Location of the study area. 
Table 1: Classification of urban wetlands in Zhuzhou City.

\begin{tabular}{|c|c|c|c|}
\hline Category & Primary type & Secondary type & Description \\
\hline \multirow{5}{*}{ Urban wetland } & Natural wetland & Riverine wetland & $\begin{array}{l}\text { Permanent river, including rivers and their tributaries, stream, waterfall } \\
\text { seasonal (has seasonal attributes) or intermittent (no obvious seasonal } \\
\text { dependence) rivers, streams, floodplains (refers to the flood of flood- } \\
\text { waters on both sides of the river) }\end{array}$ \\
\hline & \multirow{4}{*}{ Artificial wetland } & Reservoirs (area greater than 8 ha) & $\begin{array}{l}\text { Reservoir, lake, barrage, water storage area formed by the dyke, park } \\
\text { wetland }\end{array}$ \\
\hline & & Pond (area less than 8ha) & $\begin{array}{l}\text { Agricultural pond, water storage pond, Aquatic ponds such as fish and } \\
\text { shrimp culture and small landscape water bodies }\end{array}$ \\
\hline & & Paddy fields & Rice fields, lotus, water bamboo fields, etc. \\
\hline & & Wastewater treatment plant & Sewage plant, treatment pool, oxidation pool, etc. \\
\hline
\end{tabular}

generally believes that urban wetlands refer to coastal and estuary, riverbanks, shallow lakes, water conservation areas, natural and artificial ponds, and wastewater treatment plants within urban areas. An ecosystem with a land-sea transitional nature (Wang \& Lv 2007).

Based on the Ramsar Convention and the wetland classification system monitored by China's current wetland survey as the main basis, referring to "China's Land Use Status Classification" (GB/T 21010-2017), and other relevant norms, combined with the actual needs of the study, urban wetlands in Zhuzhou City are divided into natural wetlands and artificial wetlands. The specific classification and description are shown in Table 1.

\section{Research Data Source}

Data source and classification: The basic data of this paper mainly includes image data and statistical data. The main contents and sources are given in Table 2.

The Landsat 8 OLI remote sensing image data of Zhuzhou City come from the Geospatial Data Cloud Platform of the Chinese Academy of Sciences Computer Network Information Center (http://www.gscloud.cn); Zhuzhou City Administrative Border (2016), Zhuzhou City wetland Survey plaque data (2010) provided by Zhuzhou municipal forestry bureau; Zhuzhou City Google HD satellite map is download- ed from the internet employing 91 graphic assistant software.

Data interpretation: Based on the analysis software of ENVI5.3, ArcGIS10.4 and ecognition, and the object-oriented information extraction method, this paper finally obtained the classification and distribution of urban wetland in Zhuzhou city in 2016 (Fig. 2) and relevant data (Table 3).

\section{Establishment of Evaluation System for Urban Wetland Ecosystem Service Value in Zhuzhou City}

From the perspective of evaluating and managing ecosystems, the Millennium Ecosystem Assessment Classification System divides ecosystem services into four categories: supply services, regulatory services, cultural services and support services (Ma 2005), which is currently the most widely used wetland ecosystem service classification system. However, this classification system confuses the intermediate and ultimate services of wetland ecosystem, leads to double counting of ecosystem services, causes the unclear causal relationship between ecosystem functions and ecosystem services, and reduces the scientificity and applicability of wetland ecosystem services value assessment results (Boyd 2007, Johnston \& Russell 2011, Nahlik et al. 2012, Ringold et al. 2013, Keeler et al. 2012, Wong et al. 2015). Therefore, the deduplication double-counting of ecosystem services has become the focus and difficulty of the refined assessment of

Table 2: Sources of data.

\begin{tabular}{|llll|}
\hline Classification & Data & Scope & Type \\
\hline \multirow{3}{*}{ Image data } & Landsat 8 OLI & Row number 123/41 & Landsat 8 OLI, 30m \\
& Zhuzhou City wetland census spot & Zhuzhou City & Shapefile \\
& Google Hd satellite maps & Zhuzhou City & TIFF \\
& Zhuzhou City administrative boundaries & Zhuzhou City & Geodatabase 2016 \\
Statistical data & Zhuzhou statistical yearbook & Zhuzhou City & Electronic document \\
& Zhuzhou water resources bulletin & Zhuzhou City & Electronic document \\
\hline
\end{tabular}


Table 3: Urban wetland types and acreage in 2016 in Zhuzhou City.

\begin{tabular}{|lll|}
\hline Urban wetland types & Area (ha) & Proportion (\%) \\
\hline Riverine wetland & 2208.9 & 8.86 \\
Reservoirs & 619.6 & 2.49 \\
Ponds & 2262.5 & 9.08 \\
Paddy fields & 19819.9 & 79.52 \\
Wastewater treatment plant & 12.2 & 0.05 \\
Total & 24923.1 & 100 \\
\hline
\end{tabular}

wetland ecosystem services and the optimal management of wetland ecosystem services (Jiang et al. 2015).

Due to the different scales and research purposes of ecosystems, wetland ecosystem services can exist in multiple classifications (Fisher et al. 2009, Costanza 2008) depending on the specific assessment environment and assessment objectives. Based on the classification of urban wetland in Zhuzhou City, this study takes the millennium ecosystem service classification as the main reference, conducts a comprehensive survey and analysis of Zhuzhou socio-economic environment and urban wetland ecological characteristics, and establishes the urban wetland ecosystem service evaluation system (Table 4) with the direct contribution to human benefits as the only criterion. Urban wetland ecosystem services are divided into ultimate services and intermediate services. The ultimate services include atmospheric composi- tion regulation, climate regulation, water storage regulation, water purification, prevention of soil erosion, biological products, water supply, tourism, and aesthetic heritage. The sum of these services is the total value of the urban wetland ecosystem services in Zhuzhou City. Intermediate services include biodiversity, water conservation, and nutrient cycling, etc. These intermediate services contribute indirectly to human well-being through the ultimate service, and by excluding these intermediate services in the calculation of total value, double counting can be avoided.

\section{CALCULATION PROCESS AND RESULTS}

The value of urban wetland ecosystem services is a dynamic variable that changes with time and space. The evaluation process needs to indicate the time and region of its calculation. Based on the relevant basic data of urban wetland, this

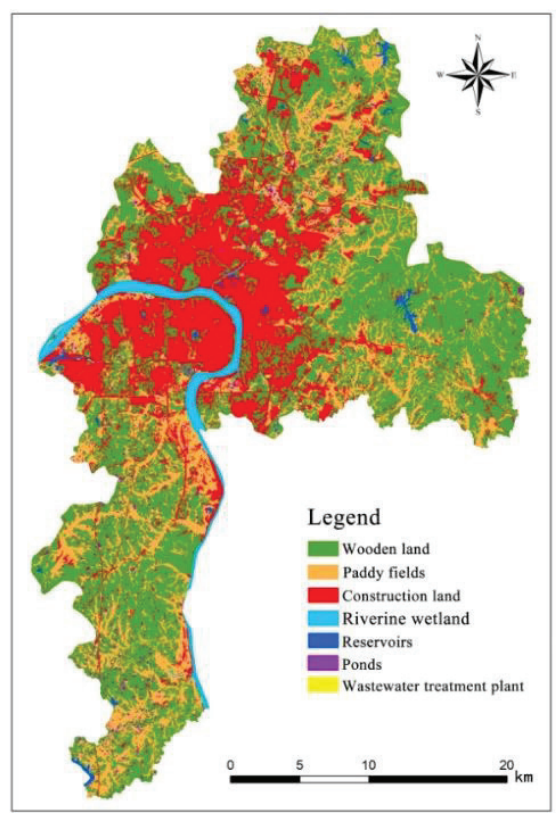

Fig. 2: Urban wetland classification in 2016 in Zhuzhou city. 
paper uses Zhuzhou City as the research scope $\left(853.4 \mathrm{~km}^{2}\right)$ in 2016 and uses the economic value evaluation method to calculate the ultimate service value and intermediate service value of urban wetland (all economic data is converted into 2016 prices based on the GDP deflator).

\section{Final Service Value}

Atmospheric composition regulation value: The adjustment value of atmospheric composition of urban wetland in Zhuzhou City mainly includes the value of oxygen release from wetland vegetation, soil carbon sequestration value and negative value of methane emission from paddy fields. It is mainly evaluated by the carbon tax value method and the market value method. The calculation equations are:

$$
V_{1}=V_{C}+V_{t}-V_{f}
$$

$$
\begin{aligned}
& V_{C}=C_{1} \times \mathrm{P}_{1} \\
& V_{t}=C_{2} \times P_{2} \\
& V_{f}=C_{3} \times P_{3}
\end{aligned}
$$

In the equations, $V_{1}$ is the value of the atmospheric composition of the wetland; $\mathrm{V}_{\mathrm{c}}$ is the total value of oxygen release (\$), $\mathrm{C}_{1}$ is the total amount of oxygen released $(\mathrm{t}), \mathrm{P}_{1}$ is the price of oxygen release $(\$ / t) ; V_{t}$ is the value of carbon sequestration of the soil (\$), $\mathrm{C}_{2}$ is Total carbon ( $\left.\mathrm{t}\right)$; $\mathrm{P}_{2}$ is carbon sequestration price $(\$ / t) ; V_{f}$ is the total methane released in paddy fields $(\mathrm{kg}), \mathrm{C}_{3}$ is the total methane release $(\mathrm{t}) ; \mathrm{P}_{3}$ is methane price $(\$ / \mathrm{t})$.

(a) Wetland carbon sequestration and oxygen release

\begin{tabular}{|c|c|c|c|c|c|}
\hline $\begin{array}{l}\text { First level } \\
\text { classifica- } \\
\text { tion }\end{array}$ & $\begin{array}{l}\text { Second level } \\
\text { classification }\end{array}$ & $\begin{array}{l}\text { Third level } \\
\text { classification }\end{array}$ & $\begin{array}{l}\text { Evaluation index and } \\
\text { parameters }\end{array}$ & $\begin{array}{l}\text { Wetland types included in } \\
\text { the calculation }\end{array}$ & Evaluation method \\
\hline \multirow{9}{*}{$\begin{array}{l}\text { Ultimate } \\
\text { Service } \\
\text { Value }\end{array}$} & \multirow{5}{*}{$\begin{array}{l}\text { regulation } \\
\text { service value }\end{array}$} & $\begin{array}{l}\text { Atmospheric composi- } \\
\text { tion Adjustment Value }\end{array}$ & $\begin{array}{l}\text { Oxygen release, Carbon } \\
\text { fixation, greenhouse } \\
\text { gas emissions (Methane } \\
\text { dominated) }\end{array}$ & $\begin{array}{l}\text { Riverine wetland, Reservoirs, } \\
\text { Pond wetlands, Paddy fields }\end{array}$ & $\begin{array}{l}\text { Carbon tax value } \\
\text { method, Industrial } \\
\text { Oxygen production } \\
\text { method }\end{array}$ \\
\hline & & $\begin{array}{l}\text { Climate Adjustment } \\
\text { Value }\end{array}$ & $\begin{array}{l}\text { Temperature changes, } \\
\text { humidity changes }\end{array}$ & $\begin{array}{l}\text { Riverine wetland, Reservoirs, } \\
\text { Pond wetlands, Paddy fields, } \\
\text { Wastewater treatment plant }\end{array}$ & $\begin{array}{l}\text { Shadow } \\
\text { project } \\
\text { method }\end{array}$ \\
\hline & & $\begin{array}{l}\text { Water Storage Adjust- } \\
\text { ment Value }\end{array}$ & $\begin{array}{l}\text { Water storage, flood } \\
\text { control and water yield } \\
\text { regulation }\end{array}$ & $\begin{array}{l}\text { Riverine wetland, Reservoirs, } \\
\text { Pond }\end{array}$ & $\begin{array}{l}\text { Shadow } \\
\text { project } \\
\text { method }\end{array}$ \\
\hline & & $\begin{array}{l}\text { Water purification } \\
\text { value }\end{array}$ & $\begin{array}{l}\text { Removed quantity of } \mathrm{N} \\
\text { and } \mathrm{P}\end{array}$ & $\begin{array}{l}\text { Riverine wetland, Reservoirs, } \\
\text { Pond }\end{array}$ & $\begin{array}{l}\text { Replacement cost } \\
\text { method }\end{array}$ \\
\hline & & $\begin{array}{l}\text { Preventing soil erosion } \\
\text { value }\end{array}$ & $\begin{array}{l}\text { Reducing land waste, re- } \\
\text { ducing soil fertility Loss }\end{array}$ & $\begin{array}{l}\text { Riverine wetland, Reservoirs, } \\
\text { Pond, Paddy fields }\end{array}$ & $\begin{array}{l}\text { Replacement cost } \\
\text { method }\end{array}$ \\
\hline & \multirow{2}{*}{$\begin{array}{l}\text { Supply ser- } \\
\text { vice value }\end{array}$} & $\begin{array}{l}\text { Biological products } \\
\text { value }\end{array}$ & Fish, rice, reed, etc. & $\begin{array}{l}\text { Riverine wetland, Reservoirs, } \\
\text { Pond, Paddy fields }\end{array}$ & Market value method \\
\hline & & Water supply value & Water consumption & Riverine wetland, Reservoirs & Market value method \\
\hline & \multirow{2}{*}{$\begin{array}{l}\text { Cultural } \\
\text { service } \\
\text { value }\end{array}$} & $\begin{array}{l}\text { Tourism recreation } \\
\text { value }\end{array}$ & $\begin{array}{l}\text { Travel cost, travel time } \\
\text { cost, consumer Surplus }\end{array}$ & $\begin{array}{l}\text { Riverine wetland, Reservoirs, } \\
\text { Pond }\end{array}$ & Travel cost method \\
\hline & & $\begin{array}{l}\text { Aesthetic heritage } \\
\text { value }\end{array}$ & $\begin{array}{l}\text { Willingness to pay, } \\
\text { willingness to accept } \\
\text { compensation }\end{array}$ & Riverine wetland, Reservoirs & $\begin{array}{l}\text { Conditional value } \\
\text { method }\end{array}$ \\
\hline \multirow{3}{*}{$\begin{array}{l}\text { Intermediate } \\
\text { Service } \\
\text { Value }\end{array}$} & & Biodiversity value & $\begin{array}{l}\text { Diversity maintenance, } \\
\text { habitat }\end{array}$ & $\begin{array}{l}\text { Riverine wetland, Reservoirs, } \\
\text { Pond }\end{array}$ & $\begin{array}{l}\text { Result reference } \\
\text { method }\end{array}$ \\
\hline & & $\begin{array}{l}\text { Water conservation } \\
\text { value }\end{array}$ & Surface water storage & River wetland, Reservoirs, Pond & $\begin{array}{l}\text { Shadow project } \\
\text { method }\end{array}$ \\
\hline & & Nutrient cycling value & $\begin{array}{l}\text { Contents of N, P and } \mathrm{K} \\
\text { in Soil }\end{array}$ & $\begin{array}{l}\text { Riverine wetland, Reservoirs, } \\
\text { Pond, Paddy fields }\end{array}$ & Shadow price method \\
\hline
\end{tabular}
positive benefits: Soil carbon sequestration: According to the relevant data, the carbon sequestration rate of the lake

Table 4: Assessment system of urban wetland ecosystem services in Zhuzhou city. 
wetland is $190.2 \mathrm{~g} / \mathrm{m}^{2}$.a (Song et al. 2011), and the soil carbon sequestration rate of the paddy fields is $380.78 \mathrm{~kg} / \mathrm{m}^{2}$.a (Han et al. 2008).

Vegetation carbon fixation and oxygen release. Different ecosystems have different carbon fixation and oxygen release standards. In this study, the river wetland takes $0.22 \mathrm{~kg} / \mathrm{m}^{2} \cdot \mathrm{a}$, and the lake wetland takes $0.15 \mathrm{~kg} / \mathrm{m}^{2} \cdot \mathrm{a}$ (Mei \& Zhang 2007). The vegetation coverage index (NDVI) is extracted from the 2016 remote sensing image interpretation map of Zhuzhou City by ArcGIS and ENVI software. After the correlation calculation, the coverage area of non-paddy wetland plants is 2,994ha, which obtained the total carbon and oxygen release of wetland vegetation in Zhuzhou City.

Oxygen-releasing carbon price: According to the industrial oxygen production method, the price of oxygen release in 2016 is $\$ 194.10 / t$. The carbon sequestration price adopts the carbon tax value method, and the 2016 conversion price is $\$ 483.77 / \mathrm{t}$.

(b) Negative methane release from rice fields: Wetlands are important sources of greenhouse gas emissions such as methane, especially in rice fields where methane emissions are large (Song 2004). The paddy fields of Zhuzhou City (99\% of rice fields) accounts for more than $80 \%$ of the total urban wetland area. Therefore, the economic value loss caused by methane emissions from rice fields is calculated as the economic value loss of greenhouse gas emissions from wetlands in Zhuzhou City. According to the relevant data, $0.36 \mathrm{~g} / \mathrm{m}^{2} \cdot \mathrm{d}$ is taken as the methane emission rate in the paddy field, and the methane emission in 410 months is taken as the total methane emission. The conversion price of methane in 2016 is $\$ 0.19 / \mathrm{kg}$ (Shangguan et al. 1994).

(c) Taking the above data into the relevant equation for calculation, the atmospheric composition regulation value of urban wetland is $\$ 92,111,687 / \mathrm{a}$.

Climate regulation value: The climate regulation value of urban wetland in Zhuzhou City mainly includes temperature regulation and increased air humidity. It is mainly evaluated by the shadow engineering method. The calculation equations are:

$$
\begin{gathered}
V_{2}=V_{Q}+V_{h} \\
\mathrm{~V}_{\mathrm{Q}}=\mathrm{ET} \div \mathrm{ER}_{\mathrm{ac}} \times \mathrm{P}_{\mathrm{e}} \\
\mathrm{V}_{\mathrm{h}}=\mathrm{EW} \times \mathrm{P}_{e w} / m^{3} \times \mathrm{P}_{\mathrm{e}}
\end{gathered}
$$

In the equations, $\mathrm{V}_{2}$ is the value of climate regulation $(\$) ; \mathrm{V}_{\mathrm{Q}}$ is the value of temperature regulation (\$); ET is the heat absorbed by total evaporation $(\mathrm{J}) ; \mathrm{ER}_{\mathrm{ac}}$ is the energy efficiency ratio of the air conditioner; $V_{h}$ is the value of air humidity (\$); EW is the amount of water evaporated $\left(\mathrm{m}^{3}\right)$;
$\mathrm{PC}_{\mathrm{ew}} / \mathrm{m}^{3}$ is the evaporation power consumption per cubic meter; $\mathrm{P}_{\mathrm{e}}$ is the electricity price $(\$ / \mathrm{kWh})$.

(a) Temperature regulation value: The annual evaporation of Zhuzhou City's waters relative to land is $14.3557 \times 10^{6}$ $\mathrm{mm}^{3}$, which is selected $2.26 \times 10^{6} \mathrm{~J} / \mathrm{kg}$ as the evaporation heat value of the water body. The energy efficiency ratio of the air conditioner is calculated according to 3.0, and the electricity price is $\$ 0.09 / \mathrm{kWh}$ in 2016 .

(b) Increase the value of air humidity: The evaporation power consumption per cubic meter of water is converted into water vapour consumption of about $125 \mathrm{kWh}$ as a parameter (Wu et al. 2016). The electricity price is taken at 2016 price of $\$ 0.09 / \mathrm{kWh}$.

(c) Taking the above data into the relevant equation for calculation, the climate regulation value of urban wetland is $\$ 424,930,361.45 / \mathrm{a}$.

Water storage adjustment value: The water storage adjustment value of urban wetland in Zhuzhou City is mainly reflected in flood control and storage, regulation of water flow and flow rate, adjustment of regional water resources, etc., mainly adopted for evaluation by shadow engineering method and protection cost method. The calculation equation is:

$$
V_{3}=\mathrm{C} \times V_{i}
$$

In the equation, $\mathrm{V}_{3}$ is the value of water storage adjustment (\$); $\mathrm{C}$ is the total amount of water storage regulation $\left(\mathrm{m}^{3}\right) ; \mathrm{V}_{\mathrm{i}}$ is the storage capacity per unit of water storage capacity $\left(\$ / \mathrm{m}^{3}\right)$.

According to the 2017 Statistical Yearbook of Zhuzhou City, the total water resources in Zhuzhou City in 2016 is 933 $\times 10^{6} \mathrm{~m}^{3}$. According to the "2001-2010 China Water Yearbook" data, the conversion cost of the unit storage capacity in 2016 is $\$ 0.58 / \mathrm{m}^{3}$. Taking the above data into the relevant equation for calculation, the water storage adjustment value of urban wetland is $\$ 539,566,265 / \mathrm{a}$.

Water purification value: The water purification value of urban wetland in Zhuzhou City is mainly reflected in the removal capacity of total nitrogen and total phosphorus in water by the wetland. It is mainly evaluated by the alternative cost method. The calculation equation is:

$$
V_{4}=\mathrm{N} \times \mathrm{S} \times V_{N}+\mathrm{P} \times \mathrm{S} \times \mathrm{V}_{\mathrm{P}}
$$

In the equation, $\mathrm{V}_{4}$ is the value of purification of wetland water (\$); $\mathrm{N}$ is the removal rate of nitrogen per unit area of the wetland; $\mathrm{P}$ is the removal rate of phosphorus per unit area of the wetland; $S$ is the area of wetland $\left(\mathrm{m}^{2}\right) ; V_{N}$ is the treatment cost of nitrogen $(\$ / \mathrm{kg}) ; \mathrm{V}_{\mathrm{p}}$ is the processing cost of phosphorus $(\$ / \mathrm{kg})$.

According to relevant data, the average removal rates 
of nitrogen and phosphorus per unit area of wetland are 3.98t/ha and 1.68t/ha, respectively (Jin et al. 2006). The total amount of nitrogen and phosphorus removed from the wetland water body is calculated based on the total area of urban wetland in Zhuzhou City. The conversion and treatment costs of $\mathrm{N}$ and $\mathrm{P}$ are $\$ 0.44 / \mathrm{kg}$ and $\$ 0.73 / \mathrm{kg}$ respectively in 2016. Taking the above data into the relevant equation for calculation, the adjusted water storage value of urban wetland is $\$ 14,598,298.19 / \mathrm{a}$.

Preventing soil erosion value: The preventing soil erosion value of urban wetlands in Zhuzhou City is mainly reflected in the reduction of land abandonment and soil fertility loss. It is mainly evaluated by the alternative cost method. The calculation equations are:

$$
\begin{gathered}
V_{5}=V_{F^{1}}+V_{F 2} \\
V_{F 1}=S_{t} \times V_{t} \\
S_{t}=M \div D, \mathrm{M}=\mathrm{P} \times \mathrm{S} \\
V_{F_{2}}=S_{t} \times D \times R \times L_{i} \times V_{i}
\end{gathered}
$$

In the equations, $\mathrm{V}_{5}$ is to prevent the value of soil erosion (\$); $\mathrm{V}_{\mathrm{F} 1}$ is to reduce the value of land abandonment (\$); $\mathrm{V}_{\mathrm{F} 2}$ is to reduce the value of soil fertility loss $(\$) ; S_{t}$ is to wasteland area $\left(\mathrm{m}^{2}\right) ; \mathrm{V}_{\mathrm{t}}$ is to reduce the cost of land abandonment per unit area $(\$ / \mathrm{ha}) ; \mathrm{M}$ is to reduce the total amount of soil erosion $\left(\mathrm{m}^{3}\right)$; D is the average thickness of soil topsoil (m); $\mathrm{P}$ is the depth of erosion $(\mathrm{m}), \mathrm{S}$ wetland area $\left(\mathrm{m}^{2}\right)$; $\mathrm{D}$ is the average thickness of soil topsoil (m), $\mathrm{R}$ is the soil bulk density $(\mathrm{g} /), \mathrm{L}_{\mathrm{i}}$ is the content of the $\mathrm{i}$-th nutrient element in the soil $(\mathrm{kg}), \mathrm{V}_{\mathrm{i}}$ is the price of the $\mathrm{i}$-th element fertilizer $(\$ / \mathrm{t})$.

(a) Reduce land waste value: Referring to relevant data, the average value of grassland erosion depth is $25 \mathrm{~mm} / \mathrm{a}$ ( $\mathrm{Li}$ et al. 2000), which calculates the total annual soil erosion of urban wetland is $6,277,500 \mathrm{~m}^{3}$ in Zhuzhou City. The average thickness of soil topsoil is $85 \mathrm{~mm}$, and the cost of reducing land per unit area is $\$ 36.97 / \mathrm{ha}$ (Wu et al. 2015). The discounted price in 2016 is $\$ 188.38 / \mathrm{ha}$.

(b) Reduce the loss of soil fertility: In this paper, the values of nitrogen, phosphorus and potassium nutrients are used to measure the value of wetland to reduce the loss of soil fertility. The bulk density of the soil is $1.2 \mathrm{~g} / \mathrm{cm}^{3}$; the average content of nutrients in the soil surface is $\mathrm{N}=1.877 \mathrm{~g} /$ $\mathrm{kg}, \mathrm{P}=0.49 \mathrm{~g} / \mathrm{kg}, \mathrm{K}=7.96 \mathrm{~g} / \mathrm{kg}$ (Li et al. 2006). The prices of nitrogen fertilizer, phosphate fertilizer and potash fertilizer in 2016 are $\$ 189.17 / \mathrm{t}, \$ 100.39 / \mathrm{t}$ and $\$ 265.85 / \mathrm{t}$, respectively.

(c) Taking the above data into the relevant equation for calculation, the soil erosion value of urban wetland is $\$ 16,911,762.05 / a$.

Biological product value: The biological products value of urban wetland in Zhuzhou City is mainly reflected in the value of freshwater animal products and rice. It is calculated based on the fishery output value and rice output value and is mainly evaluated by the market value method. The calculation equation is:

$$
V_{6}=V_{y}+V_{d}
$$

In the equation, $\mathrm{V}_{6}$ is the value of the biological product $(\$) ; V_{y}$ is the output value of the fishery $(\$) ; V_{d}$ is the output value of the rice $(\$)$.

According to the 2017 Statistical Yearbook of Zhuzhou City, the total annual fishery output value in 2016 is $\$ 27,480,422$; the total output value of rice is $\$ 94,507,530$. Taking the above data into the relevant equation for calculation, the biological products value of urban wetland is $\$ 121,987,951 / \mathrm{a}$.

Water supply value: The water supply value of urban wetland in Zhuzhou City is mainly reflected in the value of water supply, including the provision of four types of water use, such as domestic water, industrial water, agricultural water, and public ecological water. It is evaluated by the market value method. The calculation equation is:

$$
V_{7}=\Sigma A_{i} \times P_{i}
$$

In the equation, $V_{7}$ is the value of water supply (\$); $A_{i}$ is the amount of water used for the $\mathrm{i}$-th use $\left(\mathrm{m}^{3}\right) ; \mathrm{P}_{\mathrm{i}}$ is the market price of water for the i-type $\left(\$ / \mathrm{m}^{3}\right)$.

According to the 2017 Statistical Yearbook of Zhuzhou City, the total water consumption in 2016 is $67.854 \times 10^{6}$ $\mathrm{m}^{3}$, of which the domestic water consumption is 71.84 $\times 10^{6} \mathrm{~m}^{3}$, the unit price is $\$ 0.24 / \mathrm{m}^{3}$, the industrial water consumption is $386.89 \times 10^{6} \mathrm{~m}^{3}$, and the unit price is $\$ 0.29$ / $\mathrm{m}^{3}$; The water and public ecological water use are $140.44 \times$ $10^{6} \mathrm{~m}^{3}$ and $79.37 \times 10^{6} \mathrm{~m}^{3}$ respectively, and the unit price is $\$ 0.02 / \mathrm{m}^{3}$. Taking the above data into the relevant equation for calculation, the supply value of the urban wetland water source is $\$ 133,183,901 / \mathrm{a}$.

Tourism recreation value: The tourism recreation value of urban wetland in Zhuzhou City is mainly reflected in the value of sightseeing and tourism in wetlands, the value of leisure and entertainment, the value of popular science education, and the value of health and fitness. This paper uses the Travel Cost Method (TCM) to evaluate the non-market value evaluation method of tourism resources based on consumer choice theory (Dong et al. 2011), which generally includes two parts: consumer expenditure and consumer surplus. Among them, consumer expenditure includes travel expenses and travel time value. This study passed the questionnaire survey (350 questionnaires are distributed, 334 valid questionnaires are returned, feedback rate is $95.43 \%$ ) and analysis 
is obtained; consumer surplus is passed through consumers. The proportional relationship between the remaining and travel expenses is obtained. The equation for calculating the value of urban wetland tourism recreation is:

$$
V_{8}=a_{1}+a_{2}+a_{3}
$$

In the equation, $\mathrm{V}_{8}$ is the value of tourism recreation for urban wetlands in Zhuzhou City; $a_{1}$ is expenditure for travel expenses; $a_{2}$ is value for travel time; $a_{3}$ is for consumer surplus.

(a) Questionnaire statistics and analysis: Local tourist spending behaviour. Table 5 shows that urban wetland in
Zhuzhou City are more attractive to surrounding residents, and the average length of recreation is 2 to 3 hours. More than half of the people who spend less than $\$ 5$ per capita have a lower per capita consumption index.

Foreign tourists' consumption behaviour: It can be seen from Table 6 that the foreign tourists of urban wetland in Zhuzhou City mainly come from neighbouring cities, and there are many forms of self-driving tour; and the number of repeated play in the past three years is relatively low; the average playtime is 2 to 4 hours; the average cost per person is $\$ 5$ to $\$ 15$ is the main.

Table 5: Analysis of local tourists' consumption behaviour.

\begin{tabular}{|c|c|c|c|}
\hline Issue & Options & Select the number of & Proportion $(\%)$ \\
\hline \multirow{7}{*}{$\begin{array}{l}\text { How many kilometres are you } \\
\text { from the wetland (park/scenic } \\
\text { area)? }\end{array}$} & Within $3 \mathrm{~km}$ & 83 & 28.23 \\
\hline & $3-5 \mathrm{~km}$ & 105 & 35.71 \\
\hline & $5-10 \mathrm{~km}$ & 84 & 28.57 \\
\hline & $10-15 \mathrm{~km}$ & 18 & 6.12 \\
\hline & $15-20 \mathrm{~km}$ & 2 & 1.02 \\
\hline & More than $20 \mathrm{~km}$ & 1 & 0.34 \\
\hline & Once & 12 & 4.08 \\
\hline \multirow{6}{*}{$\begin{array}{l}\text { How many times a year do you } \\
\text { visit urban wetland (park/scenic } \\
\text { area)? }\end{array}$} & Twice & 21 & 7.14 \\
\hline & 3 times & 46 & 15.65 \\
\hline & 4 times & 32 & 11.22 \\
\hline & 5 times & 27 & 9.18 \\
\hline & 6 to 10 times & 64 & 21.77 \\
\hline & Once and twice a week & 46 & 15.65 \\
\hline \multirow{7}{*}{$\begin{array}{l}\text { How do you travel to urban wet- } \\
\text { land (park/scenic area)? }\end{array}$} & Almost every day & 45 & 15.31 \\
\hline & Walk & 74 & 25.17 \\
\hline & Bus & 107 & 36.39 \\
\hline & Self-driving & 81 & 27.55 \\
\hline & A bicycle / battery car / motorcycle & 19 & 6.8 \\
\hline & Taxi & 12 & 4.08 \\
\hline & Less than 1 hour & 70 & 23.81 \\
\hline \multirow{3}{*}{$\begin{array}{l}\text { How long did you spend in ur- } \\
\text { ban wetland (park/scenic area)? }\end{array}$} & 2 to 3 hours & 176 & 59.86 \\
\hline & 3 to 4 hours & 33 & 11.22 \\
\hline & 4 to 5 hours & 8 & 3.06 \\
\hline \multirow{7}{*}{$\begin{array}{l}\text { What is the cost of your visit } \\
\text { to urban wetland (park/scenic } \\
\text { area)? }\end{array}$} & 6 hours and more & 6 & 2.04 \\
\hline & Less than $\$ 5$ & 174 & 59.18 \\
\hline & $\$ 5$ to $\$ 15$ & 76 & 25.85 \\
\hline & $\$ 15$ to $\$ 30$ & 29 & 9.86 \\
\hline & $\$ 30$ to $\$ 45$ & 8 & 2.72 \\
\hline & $\$ 45$ to $\$ 75$ & 5 & 1.7 \\
\hline & More than $\$ 75$ & 2 & 0.68 \\
\hline
\end{tabular}


(b) Travel expenses: According to the preliminary questionnaire survey, the average daily travel cost of local tourists is $\$ 9.94$, and the average daily travel cost of foreign tourists is $\$ 21.84$. From this, the average daily travel cost of urban wetland in Zhuzhou City is about $\$ 12.35 /$ person. In 2016, the total number of tourists in Zhuzhou City is 27.1579 million. The number of wetland tourists is estimated based on $30 \%$ of the total number.

(c) Travel time value: Travel time value $=$ number of visitors $\times$ total travel time $\times$ spent unit time opportunity wage cost. The travel time value is calculated according to the per capita disposable income of the urban population of Zhuzhou City $\$ 5546.39$ in 2016 , and the opportunity cost is calculated according to one-third of the wage cost (Chavas et al. 1989). The monthly working hours of tourists from all sources are 168 hours. The travel time of local tourists is calculated as 0.5 hours; the travel time of non-local tourists is calculated as 2 hours. Recreation time is calculated as 3 hours. (d) Consumer surplus: According to related research, consumer surplus is generally calculated at $40 \%$ of travel expenses (Li 2006).

(e) Taking the above data into the relevant equation for calculation, the tourism recreation value of urban wetland is $\$ 174,543,328.31 / \mathrm{a}$.

Aesthetic heritage value: The aesthetic heritage value of urban wetland in Zhuzhou City is mainly reflected in the nonuse value of the invisible resources such as culture, history, aesthetic sources and species in the wetland.

In this paper, the Conditional Value Method (CVM) is mainly used for evaluation. The value of urban wetland cultural heritage in Zhuzhou City is calculated by building a hypothetical market to know people's willingness to pay for non-market items (WTP) or to obtain wiliness to accept (WTA) (Zhuang 2006). Its calculation equation is:

$$
\mathrm{V}_{9}=\mathrm{V}_{\mathrm{wtp}} \times \mathrm{A}
$$

Table 6: Analysis of consumption behaviour of foreign tourists.

\begin{tabular}{|c|c|c|c|}
\hline Issue & options & Select the number of & Proportion $1 \%$ \\
\hline \multirow{6}{*}{$\begin{array}{l}\text { How do you come to Zhuzhou } \\
\text { City? }\end{array}$} & Self-driving & 16 & 40 \\
\hline & Automobile & 7 & 17.5 \\
\hline & Ordinary train & 7 & 17.5 \\
\hline & High-speed rail/bullet train & 8 & 20 \\
\hline & Aircraft & 2 & 5 \\
\hline & Other & 0 & 0 \\
\hline \multirow{7}{*}{$\begin{array}{l}\text { In the past three years, have } \\
\text { you visited urban Wetland } \\
\text { (Park / Scenic spot) in Zhu- } \\
\text { zhou City? }\end{array}$} & Once & 11 & 27.5 \\
\hline & Twice & 13 & 32.5 \\
\hline & Three times & 9 & 22.5 \\
\hline & Four times & 0 & 0 \\
\hline & Five times & 4 & 10 \\
\hline & 6-10 times & 1 & 2.5 \\
\hline & 10 hours and more & 2 & 5 \\
\hline \multirow{5}{*}{$\begin{array}{l}\text { How long do you spend in } \\
\text { urban Wetland (Park / Scenic } \\
\text { spot) in Zhuzhou City? }\end{array}$} & Less than 1 hour & 5 & 12.5 \\
\hline & 2 to 3 hours & 23 & 57.5 \\
\hline & 3 to 4 hours & 7 & 17.5 \\
\hline & 4 to 5 hours & 2 & 5 \\
\hline & 6 hours and more & 3 & 7.5 \\
\hline \multirow{6}{*}{$\begin{array}{l}\text { How much do you spend on } \\
\text { visiting urban Wetland (Park / } \\
\text { Scenic spot) in Zhuzhou City? }\end{array}$} & Less than $\$ 5$ & 7 & 17.5 \\
\hline & $\$ 5$ to $\$ 15$ & 15 & 37.5 \\
\hline & $\$ 15$ to $\$ 30$ & 8 & 20 \\
\hline & $\$ 30$ to $\$ 45$ & 6 & 15 \\
\hline & $\$ 45$ to $\$ 75$ & 2 & 5 \\
\hline & More than $\$ 75$ & 2 & 5 \\
\hline
\end{tabular}


In the equation, $\mathrm{V}_{9}$ is for the aesthetic heritage value (\$); $\mathrm{V}_{\text {wtp }}$ is for the WTP value (\$); $\mathrm{A}$ is the number of permanent residents in Zhuzhou City.

(a) CV questionnaire design: Relevant data are collected through the development of the wetland aesthetic heritage value questionnaire. Using a district survey, East area of Xiangjiang River issued 150 questionnaires and recovered 150 copies (including 4 unqualified questionnaires); West area of Xiangjiang River issued 200 questionnaires and recovered 200 copies (including 12 unqualified questionnaires). Besides, the survey covers all types of people.

(b) Analysis of survey results: To facilitate statistics, 3,674 pieces of valid 334 questionnaires are entered into Excel software to establish a CVM questionnaire database. As given in Table 7, the willingness to pay (WTP) produced two calculation results, one is the WTP average of $\$ 18.24$, and the other is the WTP median value of $\$ 8.10$. According to the actual situation, it is known that taking the arithmetic mean to calculate the per capita maximum willingness to pay will produce a higher error. Therefore, this paper obtained the WTP median value of $\$ 8.10$ through the interpolation method and took it as the calculation standard of the paper's willingness to pay (WTP). Besides, the 2017 Yearbook shows that the resident population of Zhuzhou City is 1.2435 million in 2016.

Taking the above data into the relevant equation for calculation, the aesthetic heritage value of urban wetland is $\$ 10,075,300 /$ a.

\section{Intermediate Service Value}

Biodiversity value: The biodiversity value of urban wetland in Zhuzhou City is mainly reflected in the important value its rich biodiversity provides for the balance of the regional ecosystem. In this paper, the achievement reference method is adopted, and its calculation equation is as follows:

$$
\mathrm{V}_{10}=\mathrm{V}_{\mathrm{c}} \times \mathrm{A}
$$

In the equation, $\mathrm{V}_{10}$ is for biodiversity value $(\$) ; \mathrm{V}_{\mathrm{c}}$ is the value of wetland per hectare biodiversity $(\$ / a)$; $\mathrm{A}$ is calculated urban wetland area (ha);

This paper studies the unit value of wetland biodiversity in the value of China's ecosystem services by Xie et al. (2015), and its 2016 conversion price is $\$ 2,892.92 / \mathrm{ha} \cdot \mathrm{a}$. Taking the above data into the relevant equation for calculation, the biodiversity value of urban wetland is $\$ 1,981.89 /$ a.

Water conservation value: The water conservation value of urban wetland in Zhuzhou City is mainly reflected in the water storage value of the wetland to the surface. This paper adopts the alternative cost method, and its calculation equation is:

$$
V_{11}=\Sigma A_{i} \times D_{i} \times P_{s}
$$

In the equation, $\mathrm{V}_{11}$ is for the conservation of water source value $(\$) ; A_{i}$ is for each type of wetland area (ha); $D_{i}$ is for each type of wetland storage depth $(\mathrm{m}) ; \mathrm{P}_{\mathrm{s}}$ is storage capacity of storage capacity $\left(\$ / \mathrm{m}^{3}\right)$.

According to the survey on the current situation of urban wetland resources in Zhuzhou City, with reference to the data of Zhuzhou City Water Resources Bulletin in 2017, the average depth of river wetland water storage in Zhuzhou City is $8 \mathrm{~m}$, and the average depth of water storage in the water storage area is $4 \mathrm{~m}$. The average depth of water is $2 \mathrm{~m}$; in 2016 ,

Table 7: Frequency distribution of sample willingness to pay.

\begin{tabular}{|lllll|}
\hline WTP value $(\$)$ & Absolute frequency / person & Relative frequency $(\%)$ & Frequency of adjustment $(\%)$ & Cumulative frequency $(\%)$ \\
\hline 5 & 51 & 15.3 & 30.2 & 46.2 \\
15 & 45 & 13.5 & 26.5 & 72.7 \\
30 & 22 & 6.6 & 13.0 & 85.7 \\
45 & 4 & 1.2 & 2.4 & 88.1 \\
60 & 0 & 0 & 0 & 88.1 \\
75 & 6 & 1.8 & 3.6 & 91.7 \\
90 & 1 & 0.3 & 0.6 & 92.3 \\
120 & 1 & 0.3 & 0.6 & 92.9 \\
150 & 3 & 0.9 & 1.8 & 94.7 \\
300 & 7 & 2.1 & 4.1 & 98.8 \\
300 and above & 2 & 0.6 & 1.2 & 100 \\
Refusal to pay & 164 & 49.2 & & \\
WTP average & 18.24 & & & \\
WTP median value & 8.10 & & & \\
\hline
\end{tabular}


Table 8: Value of urban wetland ecosystem service in Zhuzhou City.

\begin{tabular}{|c|c|c|c|c|c|}
\hline $\begin{array}{l}\text { Primary } \\
\text { classification }\end{array}$ & $\begin{array}{l}\text { Secondary } \\
\text { classification }\end{array}$ & $\begin{array}{l}\text { Tertiary } \\
\text { classification }\end{array}$ & Value $\left(\$ 10^{6} \cdot \mathrm{a}\right)$ & Unit value ( $\left.\$ 10^{3} / \mathrm{ha}\right)$ & $\begin{array}{l}\text { Proportion of to- } \\
\text { tal value }(\%)\end{array}$ \\
\hline \multirow{9}{*}{$\begin{array}{l}\text { Ultimate ser- } \\
\text { vice value }\end{array}$} & \multirow{5}{*}{$\begin{array}{l}\text { Adjust service } \\
\text { value }\end{array}$} & Adjustment value of atmospheric composition & 92.1117 & 3.7 & 6.03 \\
\hline & & Climate regulation value & 424.9304 & 17 & 27.81 \\
\hline & & Water storage regulation value & 539.5663 & 21.7 & 35.31 \\
\hline & & Water quality purification value & 96.9327 & 0.6 & 0.96 \\
\hline & & Value of preventing soil erosion & 16.9118 & 0.7 & 1.11 \\
\hline & \multirow{2}{*}{$\begin{array}{l}\text { Supply service } \\
\text { value }\end{array}$} & Biological product value & 121.9880 & 4.9 & 7.98 \\
\hline & & Water supply value & 3.2002 & 5.3 & 8.72 \\
\hline & \multirow{2}{*}{$\begin{array}{l}\text { Cultural service } \\
\text { value }\end{array}$} & Tourism rest value & 26.2866 & 7 & 11.42 \\
\hline & & Aesthetic heritage value & 10.0753 & 0.4 & 0.66 \\
\hline Total & & & $1,527.9089$ & 61.3 & 100.00 \\
\hline \multirow{3}{*}{$\begin{array}{l}\text { Intermediate } \\
\text { service value }\end{array}$} & & Biodiversity value & 19.8189 & - & 11.43 \\
\hline & & Water conservation value & 142.6964 & - & 82.33 \\
\hline & & Nutritional cycle value & 10.8107 & - & 6.24 \\
\hline Total & & & 173.326 & - & 100.00 \\
\hline
\end{tabular}

the cost of the unit reservoir is $\$ 0.58 / \mathrm{m}^{3}$; the area of each type of wetland is shown in Table 3. Taking the above data into the relevant equation for calculation, the water conservation value of urban wetland in Zhuzhou City is \$142,696,482/a.

Nutritional cycle value: The nutritional cycle value of urban wetland is mainly reflected in the value of $\mathrm{N}, \mathrm{P}, \mathrm{K}$ and other nutrients in the utilization, conversion, movement and reuse of ecosystems. In this paper, the shadow price method and the soil bank nutrient retention method are used to evaluate the value. The calculation equation is:

$$
V_{12}=S_{t} \times D \times R \times L_{i} \times V_{i}
$$

In the equation, $\mathrm{V}_{12}$ is for the nutritional cycle value $(\$) ; S_{t}$ is for the wetland area $\left(\mathrm{m}^{2}\right)$; D is for the soil topsoil average thickness (m); $\mathrm{R}$ is for the soil bulk density $\left(\mathrm{g} / \mathrm{cm}^{3}\right)$; $\mathrm{L}_{\mathrm{i}}$ is for the soil $\mathrm{N}, \mathrm{P}, \mathrm{K}$ nutrient content $(\mathrm{kg}) ; \mathrm{V}_{\mathrm{i}}$ is the price of $\mathrm{N}, \mathrm{P}, \mathrm{K}$ fertilizer $(\$ / \mathrm{t})$.

In this paper, the average thickness of soil surface layer in Zhuzhou City is calculated according to $85 \mathrm{~mm}$ ( $\mathrm{Li}$ et al. 2006), the bulk density of soil is $1.2 \mathrm{~g} / \mathrm{cm}^{3}$, and the average content of nutrient elements in soil surface is $\mathrm{N}=1.877 \mathrm{~g} / \mathrm{kg}$,

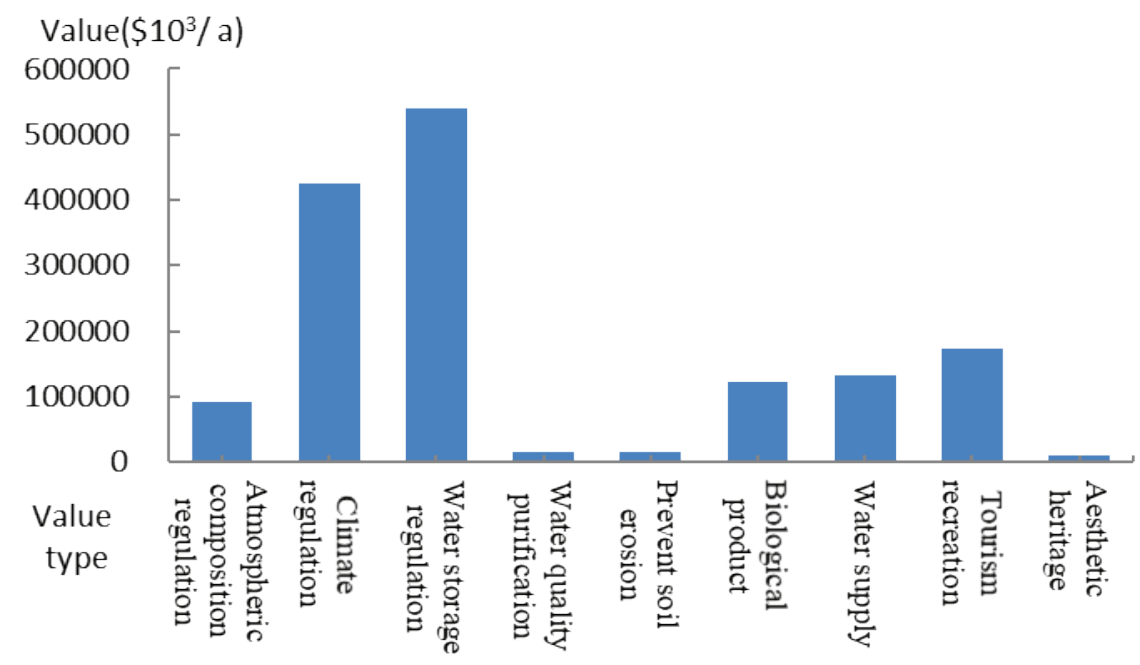

Fig. 3: Histogram of urban wetland value statistics. 
$\mathrm{P}=0.49 \mathrm{~g} / \mathrm{kg}, \mathrm{K}=7.96 \mathrm{~g} / \mathrm{kg}$ (Dong et al. 2011). The prices of nitrogen fertilizer, phosphate fertilizer and potash fertilizer in 2016 are $\$ 189.17 / \mathrm{t}, \$ 100.39 / \mathrm{t}$ and $\$ 264.49 / \mathrm{t}$, respectively. Taking the above data into the relevant equation for calculation, the nutritional cycle value of urban wetland is $\$ 10,810,707.8 / a$.

The total value of urban wetland ecosystem service in Zhuzhou City: The total value of urban wetland ecosystem service in Zhuzhou City is the sum of the ultimate service values of wetlands. The calculation equation is:

$$
V_{s}=\Sigma_{1}^{9} V_{i}
$$

In the equation, $\mathrm{V}_{\mathrm{s}}$ is the total value of service for wetlands (\$); $\mathrm{V}_{\mathrm{i}}$ refers to the value of the i-type value (\$) in the ultimate service value.

After calculation, the ultimate service value of urban wetland is $\$ 1,527,908,901$; the intermediate service value of urban wetland is $\$ 173,326,054$. The total value of urban wetland ecosystem services in Zhuzhou City in 2016 is $\$ 1,527,908,901$ (Table 8).

Statistical analysis of urban wetland ecosystem service value in Zhuzhou City: The statistics of the ultimate service value of different urban wetland types in Zhuzhou City are shown in Table 9.

\section{Analysis of the ultimate service values of urban wetland:} The ultimate value of the urban wetland ecosystem services in Zhuzhou City is ranked as follows: Water storage regulation value $>$ Climate regulation value $>$ Tourism recreation value $>$ Water supply value $>$ Biological product value $>$ Atmospheric composition regulation value $>$ Preventing soil erosion value $>$ Water purification value $>$ Aesthetic heritage value, as shown in Fig. 3.
Analysis of the value of each type of urban wetland: The value of different types of urban wetland types in Zhuzhou City is as follows: Paddy fields $>$ Riverine wetland $>$ Ponds $>$ Reservoir $>$ Wastewater treatment plant, as shown in Fig. 4.

Analysis of unit area value of each type of urban wetland: The value per unit area of each type of urban wetland in Zhuzhou City is ranked as follows: Reservoirs $>$ Riverine wetland $>$ Pond $>$ Paddy fields $>$ Wastewater treatment plant, as shown in Fig. 5.

\section{DISCUSSION AND CONCLUSIONS}

Compared with previous wetland research, this paper focuses on urban wetland ecosystem services, and distinguishes the intermediate service value and ultimate service value of urban wetland ecosystem in the process of constructing service evaluation system, and comprehensively evaluates the direct contribution of the wetland ecosystem of Zhuzhou City to human welfare. From the perspective of the selection of evaluation indicators and methods, the evaluation results of this study are reasonable to some extent, and the value assessment methods are improved compared with the previous ones, providing a reference for the refined evaluation of urban wetland ecosystem service value.

However, part of the economic data has a long time, it has a certain impact on the evaluation results of the paper. Besides, it should be pointed out that deduplicate double-counting not only improves the accuracy and accuracy of ecological service value accounting but also provides a more scientific decision-making basis for urban wetland conservation and management. As a result, the wetland value can be

Table 9: The ultimate service values of different types of urban wetlands in Zhuzhou City.

\begin{tabular}{|c|c|c|c|c|c|c|}
\hline Value types & $\begin{array}{l}\text { Riverine wet- } \\
\text { land } / \$ 10^{3}\end{array}$ & $\begin{array}{l}\text { Reservoir / } \\
\$ 10^{3}\end{array}$ & ponds $/ \$ 10^{3}$ & $\begin{array}{l}\text { Paddy fields } \\
/ \$ 10^{3}\end{array}$ & $\begin{array}{l}\text { Wastewater treat- } \\
\text { ment plant } / \$ 10^{3}\end{array}$ & Total value $/ \$ 10^{3}$ \\
\hline Atmospheric composition regulation & $3,059.8$ & 14,325 & $10,025.3$ & $77,594.2$ & - & $92,111.7$ \\
\hline Climate regulation & $37,660.9$ & 10,564 & $38,574.8$ & $337,922.8$ & 207.8 & $424,930.4$ \\
\hline Water storage adjustment & $241,412.1$ & $53,647.1$ & $244,507.1$ & - & - & $539,566.3$ \\
\hline Water purification & 6,334 & $1,776.7$ & $6,487.7$ & - & - & $14,598.3$ \\
\hline Prevent soil erosion & 357.7 & 100.4 & 366.6 & $16,087.2$ & - & $16,911.8$ \\
\hline Biological product & $11,923.3$ & $3,344.5$ & $12,212.6$ & $94,507.5$ & - & 121,988 \\
\hline Water supply & $108,968.6$ & $24,215.3$ & - & - & - & $133,183.9$ \\
\hline Tourism recreation & 104,726 & 52,363 & $17,454.3$ & - & - & $174,543.3$ \\
\hline Aesthetic heritage & $8,243.5$ & $1,831.9$ & - & - & - & $10,075.3$ \\
\hline Total value of wetland & $522,685.8$ & $149,275.2$ & $329,628.3$ & $526,111.7$ & 207.8 & $1,527,908.9$ \\
\hline Proportion of the total value/ $\%$ & 34.21 & 9.77 & 21.57 & 34.43 & 0.01 & 100 \\
\hline Unit value $/ \$ 10^{3} /$ ha & 236.6 & 240.9 & 145.7 & 26.6 & 17 & 61.3 \\
\hline
\end{tabular}




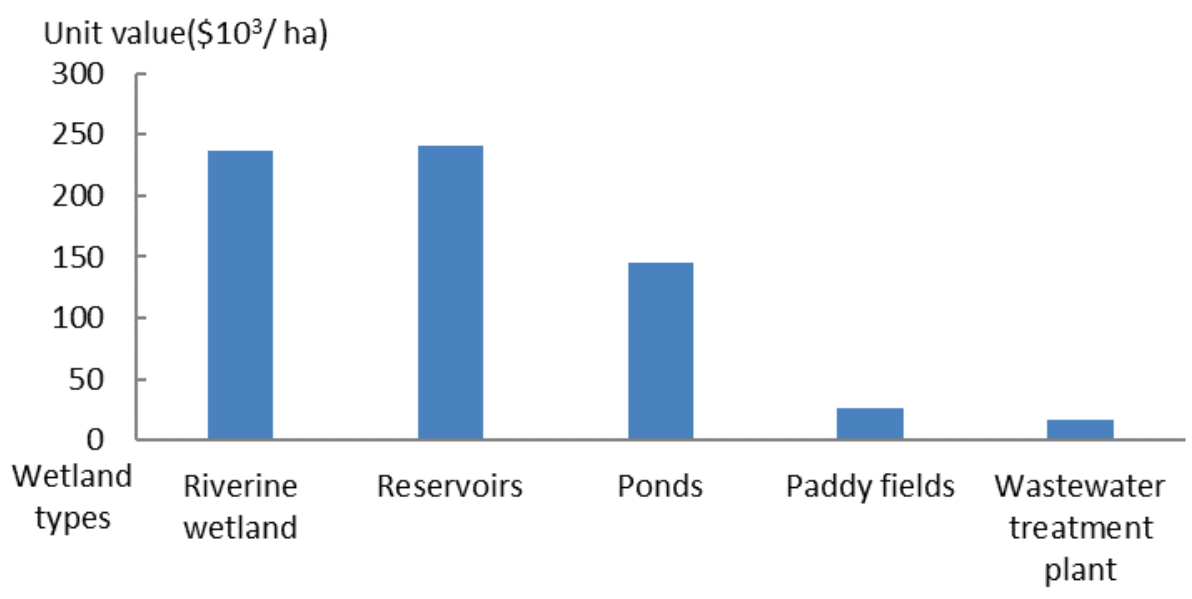

Fig. 4: Total value statistics of urban wetland types.

used to evaluate the results of science into city management decision-making system. For an important direction of urban wetland research and practical application, we need to further grasp the urban wetland ecosystem structure, process, function and service-related mechanism, clear the city spatial flow and transfer characteristic of wetland ecosystem services, clear the ultimate service directly linked with the beneficiaries, adopt more reasonable calculation, establish more scientific and comprehensive wetland ecological service evaluation system, make urban wetland ecosystem service research from the evaluation to the management practice.

Based on 2016, Zhuzhou wetland remote sensing image interpretation map, this paper establishes the urban wetland ecosystem service evaluation system according to the urban wetland classification in Zhuzhou City, combined with the field investigation and relevant basic data, and uses the economic value evaluation method to calculate urban wetland ecology system service value and comprehensive analysis of the evaluation results. The relevant conclusions are as follows:

(a) As of 2016, the total urban wetland area in Zhuzhou City is about $24,923 \mathrm{ha}$, which is divided into five types: riverine wetland, reservoir, ponds, paddy fields, and wastewater treatment plants. The area of paddy fields is the largest, accounting for $19,820 \mathrm{ha}$, accounting for $79.52 \%$ of the total urban wetland area. This indicates that as one of the main producing areas of rice in southern China, paddy fields is an important part of urban wetland in Zhuzhou City. It not only provides the city with material products but also plays an outstanding

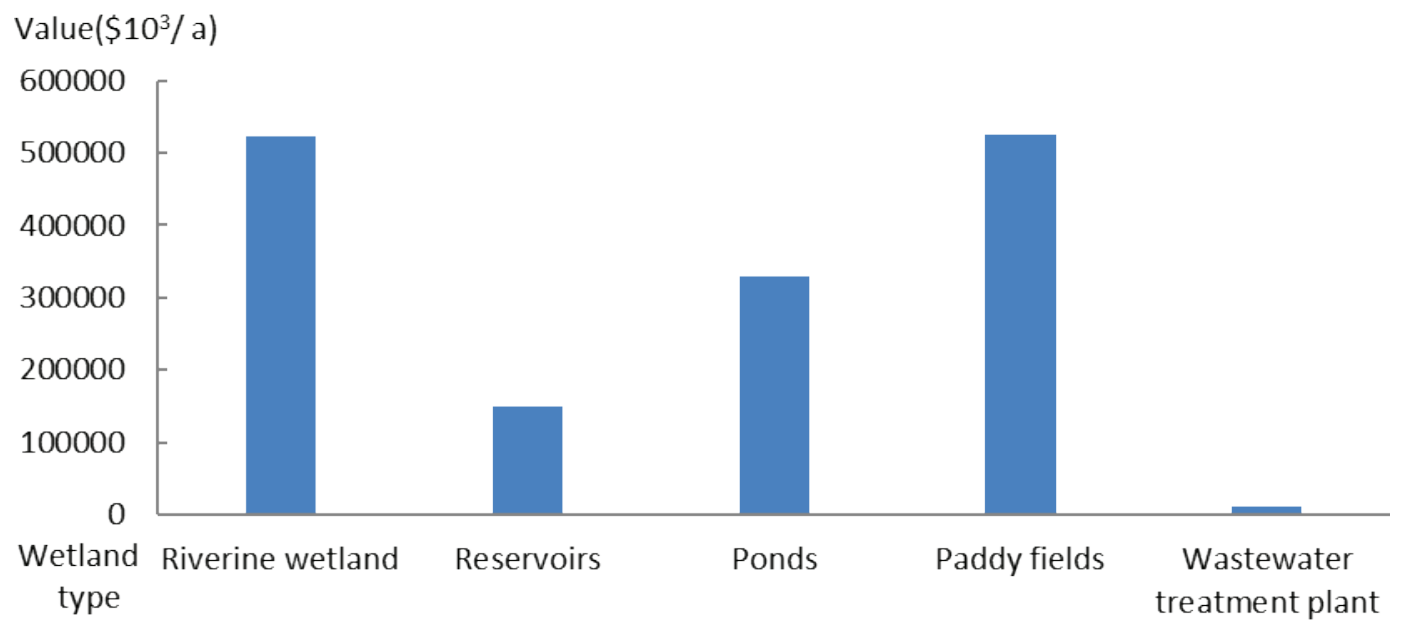

Fig. 5: Unit area value statistics of urban wetland types. 
ecological service function. Therefore, it should continue to strengthen protection and management, and illegal occupation, ruin and destruction of paddy fields are strictly prohibited.

(b) In this paper, the urban wetland ecosystem service evaluation system in Zhuzhou City is constructed, and it is divided into ultimate service and intermediate service through deduplicate double counting. The ultimate service incorporates the total value calculation of wetland ecosystem services, while the intermediate services are excluded from the total value, which indirectly contributes to human well-being through the ultimate service. The evaluation index system provides an important direction for distinguishing the intermediate services (functions) and ultimate services of urban wetland ecosystems, and developing dynamic assessment and optimal management of urban wetland ecosystem ultimate services.

(c) In 2016, the total value of urban wetland ecosystem services in Zhuzhou City is about $\$ 166,333,305.72$, of which the ultimate service value was about $\$ 166,333,305.72$, the intermediate service value is about $\$ 173,326,054.2$. The urban wetland unit area ecosystem service value is about $\$ 61,310.24 / \mathrm{ha}$; The total value accounts for $8.63 \%$ of the total GDP of Zhuzhou City in the same year, which reveals the great contribution of wetland system services to urban development.

(d) The value of water storage regulation and climate regulation the largest among all ecological services of urban wetland in Zhuzhou City, which are about $\$ 539,566,265.1 / \mathrm{a}$ and $\$ 424,930,361.4 / \mathrm{a}$, respectively. The sum of the two values accounts for $63.13 \%$ of the total value of urban wetland ecosystem services. This indicates that the urban wetland is the most important source of water vapour and climate regulators in Zhuzhou City, and water storage regulation and climate regulation are the core services provided by the wetlands to the city.

(e) Among all types of urban wetlands in Zhuzhou City, the value of paddy fields and riverine wetland is the highest, which is about $\$ 526,111,671.7 / \mathrm{a}$ and $\$ 522685813.3$ /a, respectively. The sum of the two values accounts for $68.64 \%$ of the total value of urban wetland ecosystem services. Besides, the reservoir and the riverine wetland have the largest unit value, which is about $\$ 240,918.67$ / ha.a and \$236,626.51/ha.a. This indicates that in the wetland conservation work of Zhuzhou City, riverine wetlands, especially the Xiangjiang River (the most important river in the region), should be the primary object, and the conservation of wetlands in reservoir wetland with large water areas should be strengthened, with the focus on guaranteeing their basic ecosystem service functions.

\section{ACKNOWLEDGEMENTS}

This research is funded by the Research Foundation of Education Bureau of Hunan Province, China (Grant No. 14B196, 18C1802, XJT2015(291)-186); Key Project of Science and Technology plan of Hunan Province, China (Grant No. 2018NK2052). This study is supported by Hunan Education Department's “12th five-year plan" Key Discipline Funding Project (2011-76); The state forestry administration's 13th five-year key discipline.

\section{REFERENCES}

Adamus, P.R., Clairain E.J. and Smith, R.D. 1987. Wetland Evaluation Technique (WET). Volume 2. Methodology. Operational draft. Final report, June 1984-September 1988 (No. PB-89-143028/XAB). Army Engineer Waterways Experiment Station, Vicksburg, MS (USA).

Brander, L.M., Florax, R.J. and Vermaat, J.E. 2006. The empirics of wetland valuation: A comprehensive summary and a meta-analysis of the literature. Environmental and Resource Economics, 33(2): 223-250.

Boyd, J. and Banzhaf, S. 2007. What are ecosystem services? The need for standardized environmental accounting units. Ecological Economics, 63(2): 616-626.

Boyd, J.W. 2007. The end point problem. Resources, 165: 26-28.

Chavas, J.P, Stoll, J. and Sellar, C. 1989. On the commodity value of travel time in recreational activities. Applied Economics, 21: 711 722.

Costanza, R. 2008. Ecosystem services: Multiple classification systems are needed. Biological Conservation, 141(2): 350-352.

Costanza, R., d'Arge, R., de Groot R. 1997. The value of the world's ecosystem services and natural capital. Nature, 387: 253-260.

Costanza, R., Groot, R.D. ,, Sutton, P., van der P.S. and Anderson, S.J. 2014. Changes in the global value of ecosystem services. Glob. Environ. Chang., 26: 152-158.

Daily, G.C. 1997. Nature's Services: Societal Dependence on Natural Ecosystems. Island Press.

De, G.R., Stuip, M., Finlayson, M. and Davidson. 2006. Valuing wetlands: Guidance for valuing the benefits derived from wetland ecosystem services. International Water Management Institute.

De, G.R., Brander L., van der P.S. and Sander. 2012. Global estimates of the value of ecosystems and their services in monetary units. Ecosystem Services, 1(1): 50-61.

De, Groot, R.S., Wilson, M.A. and Boumans, R.M. 2002. A typology for the classification, description and valuation of ecosystem functions, goods and services. Ecological Economics, 41(3): 393-408.

Dong, X.W., Zhang, J. and Zhang, J.H. 2011. Review on several issues of travel cost method in tourist resources valuation. journal of natural resources. Journal of Natural Resources, 26(11): 1983-1997.

Braat, L.C. and De Groot, R., 2012. The ecosystem services agenda: bridging the worlds of natural science and economics, conservation and development, and public and private policy. Ecosystem Services, 1(1): 4-15.

Farley, J., Costanza, R. 2010. Special Section: Payments for ecosystem services: From local to global. Ecol. Econ., 69: 2060-2068.

Fisher, B. and Kerry, T.R. 2008. Ecosystem services: classification for valuation. Biological Conservation, 141(5): 1167-1169.

Fisher, B., Turner, K., Zylstra, M. Brouwer, R., Groot, R. D. and Farber, S. 2008. Ecosystem services and economic theory: Integration for policy-relevant research. Ecological Applications, 18(8): 2050-67. 
Fisher, B., Turner, R.K. and Morling, P. 2009. Defining and classifying ecosystem services for decision making. Ecological Economics, 68(3): 643-653.

Han, B., Wang, X.K., Lu F., Duan X.N. and OuYany Z.Y.. 2008. Soil carbon sequestration and its potential by cropland ecosystems in China. Acta Ecologica Sinica., (02): 612-619.

Hawkins, K. 2003. Economic Valuation of Ecosystem Services. University of Minnesota, 23.

Hoekstra, A.Y. and Hung, P. 2002. Virtual water trade. A quantification of virtual water flows between nations in relation to international crop trade. Value of Water Research Report Series, 11: 166.

Jiang, B., Zhang L. and Ouyang, Z.Y. 2015. Ecosystem services valuation of Qinghai Lake. The Journal of Applied Ecology, 26(10): 3137-3144.

Jin, X.C., Jiang, X., Xu, Y.H. and Wang, Q. 2006. Seasonal variation of dissolved nitrogen and phosphorus in sediments in northeast part of Lake Taihu. China Environmental Science, 26(4): 409-413.

Johnston, R.J. and Russell, M. 2011. An operational structure for clarity in ecosystem service values. Ecological Economics, 70: 2243-2249.

Keeler, B.L., Polasky, S., Brauman, K.A., Johnson, K.A. and Finlay, J.C. 2012. Linking water quality and well-being for improved assessment and valuation of ecosystem services. Proceedings of the National Academy of Sciences of the United States of America, 109: 18619-18624.

Li, C.J., Lu, H.B., Xu J.H. and Wang, Z.C. 2000. Problem on calculation of soil and water conservation benefit. Bulletin of Soil and Water Conservation, 3: 29-30.

Li, C.Y., Hua, D.Z., Ren, J. and Li, M.L. 2006. The benefit value estimate of anti-erosion of the urban wetland soil of Songbei District of Harbin. Research of Environmental Sciences, 6: 135-138.

Li, J.N. 2006. Studies on the Ecosystem Services of Xixi Wetland, Hangzhou. Chongqing Southwest University, 8: 32-35.

Mei, X.Y. and Zhang, X.F. 2007. Carbon storage and carbon fixation during the succession of natural vegetation in wetland ecosystem on east beach of Chongming Island. Chinese Journal of Applied Ecology, (04): 933-936.

Musamba, E.B., Boon, E.K., Ngaga, Y.M. and Dumulinyi. 2012. The recreational value of wetlands: Activities, socio-economic activities and consumers' surplus around Lake Victoria in Musona municipality, Tanzania. Journal of Human Ecology, 37(2): 85-92.

Millennium Ecosystem Assessment (MA) 2005. Ecosystems and Human Well-Being: Wetlands and Water Synthesis. Washington, DC: Island Press.

Nahlik, A.M., Kentula, M.E., Fennessy M.S. and Landers, D. H. 2012. Where is the consensus? A proposed foundation for moving ecosystem service concepts into practice. Ecological Economics, 77: 27-35.

Nelson, E., Mendoza, G., Regetz, J., Polasky, J., Chan, K.M.A. and Daily, G.C. 2009. Modeling multiple ecosystem services, biodiversity conservation, commodity production, and trade-offs at landscape scales. Frontiers in Ecology and the Environment, 7(1): 4-11.

Odum, H.T. and Nilsson, P. 1996. Environmental Accounting. Energy and
Environmental Decision Making. Wiley New York.

Ringold, P.L., Boyd, J., Landers, D. 2013. What data should we collect? A framework for identifying indicators of ecosystem contributions to human well-being. Frontiers in Ecology and the Environment, 11: 98-105.

Shangguan, J.X., Wang, M.X., Shen, R.X., Wang, Y.S., R Wassmann and H.Rennenberg. 1994. The feature of methane emission from a paddy field in the Central China Region. Scientia Atmospherica Sinica, 3: 358-365.

Song, C.C. 2004. Advance in the studies on methane emission from wetlands. Ecology and Environment, (1): 69-73.

Song, H.T., Cui, L.J., Luan, J.W., Duan X.N. and OuYany Z.Y. 2011. Wetland function and potential in carbon sequestration. World Forestry Research, 24(06): 6-11.

Sun, B., Lei, Y., Cui, L. Wei, L., Xiaoming, K. and Manyin, Z. 2018. Addressing the modelling precision in evaluating the ecosystem services of coastal wetlands. Sustainability, 10: 1136.

Turner, R.K., Morse, J.S. and Fisher, B. 2010. Ecosystem valuation: A sequential decision support system and quality assessment issues. Annals of the New York Academy of Sciences, 1185: 79-101.

The Economics of Ecosystems and Biodiversity (TEEB) 2010. The Economics of Ecosystems and Biodiversity: Ecological and Economic Foundations. Earthscan, London.

United States Environmental Protection Agency (USEPA) 2009. Valuing the Protection of Ecological Systems and Services. Washington DC: US EPA.

Wallace, K.J. 2007. Classification of ecosystem services: Problems and solutions. Biological Conservation, 139(3): 235-246.

Wang, J.H. and Lv, X.G. 2007. Urban wetland: Its concept, ecological services and protection. Chinese Journal of Ecology, 4: 555-560.

Wong, C.P., Jiang, B., Kinzig, A.P., Lee Kai N and OuYany Z.Y. 2015. Linking ecosystem characteristics to final ecosystem services for public policy. Ecology Letters, 18: 108-118.

Woodward, R.T. and Wui, Y.S. 2001. The economic value of wetland services: A meta-analysis. Ecological Economics, 37(2): 257-270.

Wu, H.J., Dan, X.Q., Liu, S.H., Huang, Y. and Shu, Y. 2016. Preliminary evaluation of wetland ecosystem services in Hunan province. Wetland Science, 14(06): 781-787.

Wu, T.F., De, X.W., Huang, W.K., Li, C,, Kang, W.X. and Cui, F. 2015. Evaluation of forest ecosystem service value in Nan County. Journal of Central South University of Forestry \& Technology, 35(10): 109-115.

Xie, G.D., Zhang, C.X., Zhang, C.S., Xiao, Y. and Lu, C.X. 2015. The value of ecosystem services in China. Resources Science, 37(09): 1740-1746.

Zhao, M. and He, Z. 2018. Evaluation of the effects of land cover change on ecosystem service values in the upper reaches of the Heihe River Basin, Northwestern China. Sustainability, 10: 4700.

Zhou, B. 2011. Study on the Evaluation Method of the Ecological Service Value of Wild Duck Lake Wetland. Capital Normal University.

Zhuang, D.C. 2006. Evaluation of the no use values of the wetland resources in Dongting Lake Based on CVM. Areal Research and Development, 2: $105-110$. 